\title{
Poemas conviviales
}

\author{
Susana Romano Sued \\ Universidad Nacional de Córdoba - \\ CONICET
}

2016 es un año particularmente rico en celebraciones, conmemoraciones y reconocimientos. Por eso, el Departamento de Letras de la Facultad de Humanidades y Ciencias decidió organizar un ciclo aniversario donde celebramos las figuras y obras de Cervantes, Shakespeare, Borges, Di Benedetto, García Lorca, Unamuno, Joyce, Pirandello, Saussure, George Sand, Simone de Beauvoir, Marguerite Duras, Umberto Eco y tantos más.

La poeta, estudiosa e integrante desde la primera hora del Comité Honorario de esta revista, Susana Romano Sued, quiso contribuir con sus poemas homenaje a cuatro de ellos. Vaya nuestro propio homenaje en la Convivial lectura.

\section{Endecasílabos quijotescos}

Conmemoro los frutos cervantinos en honra y memoria del hidalgo el verso suelto ajusto y encabalgo a puro castellano mi destino

En cada idioma vive, suena y canta su cuarto centenario el caballero desdoblado en fiel sombra: el escudero quien del amo el sinsentido espanta

La cruzada libresca y azarosa narrada gloria trae a nuestra mente abierta y lista al sueño vehemente arremolina ejércitos de prosa

Ardido en el culto aventurero pródiga letra y frase venturosa traspone las palabras y las cosas al crisol de los signos extranjeros

El barquero entre lenguas alejadas lleva el rumor inquieto de los sueños de aquel manchego que no tuvo dueños sino la dulce dama bienamada: 
En su sentencia Borges me ha mostrado que Don Quijote es múltiple y es uno que Pierre Menard es todos y es alguno vertedor del idioma empecinado

Legados cervantinos conmemoro en honra y en memoria del hidalgo el verso suelto ajusto y encabalgo es puro castellano, y es tesoro.

\section{Borgesiana Verbomaquia}

A Jorge Luis Borges

Ni en caricias la mano figurada ni en la boca el amor que se desglosa ni en la esencia o aroma está la rosa ni en el cuello está el beso de la amada

Y se hace cuerpo solo al ser nombrada la palabra en que se halla cada cosa y que el silencio torna misteriosa y la voz la retorna renovada

$\mathrm{Al}$ principio está el verbo que se posa en el lugar incierto de la nada y hace nacer al hombre y a la esposa

Y evoca con el nombre dado a cada instancia, que al decir deviene cosa que niega su existencia si es callada. 
Soneto de ocaso

A William Shakespeare

A buen fin mejor principio, nos decía de Stratford el maestro de la escena. Epocales momentos, nuevas eras acaso en aquel drama presentía

Mejor comienza lo que bien termina, la frase de comedia se recuesta sobre el final y sobre cada apuesta donde nuestro destino se encamina

el tiempo con sigilo se desgrana como roja granada, como espiga y acaba de contarse en la fatiga

circular es su esencia y es lejana sobre sí rota el año sucesivo y en vez de cierto nos parece esquivo.

\section{Semeion}

Para Umberto Eco

En busca de la lengua más perfecta así como el nombre de una rosa en las obras abiertas y preciosas tu pendular trazaba líneas rectas.

Decir casi lo mismo, preferiste al señalar los ardides de las lenguas para pasar de una a otra sin la mengua que traductores tratan; y es muy triste.

Umberto me enseñaste tantas cosas que suenan como un eco en mi cerebro la risa es abalorio que yo enhebro.

Lejos de los extremos blanco y negro conmemoro tus voces amorosas que reverberan y así yo te celebro. 
